\title{
Optimization Carotenoids Isolation Of The Waste Crude Palm Oil Using $\alpha$-Amylase, $\beta$-Amylase, And Cellulase
}

\author{
Sumi Hudiyono*, Ardi Septian \\ Department of Chemistry, Faculty of Mathematics and Science, University of Indonesia \\ Depok 16424, Indonesia
}

\begin{abstract}
Waste oil industry has a great potential use, as $77 \%$ oil yield are an untapped waste that still has a high economic value as a base for the oleochemical industry, one of which is $\beta$-carotene. The study was conducted to optimize the extraction of carotenoids from Crude Palm Oil (CPO) and Palm Oil Mill Effluent waste (POME) conducted by column chromatography and extraction method with a single enzyme : $\alpha$-amylase, $\beta$-amylase, or cellulase and its mixed. In addition, the saponification reaction performed on CPO to separate unsaponifiable fraction by the addition of enzyme pretreatment. The results showed that the extraction of carotenoids with the help of enzymes better than separation prossses using the column chromatography. $\alpha$ Amylase, $\beta$-amylase, and cellulase may help release carotenoids from the matrix of fibers and other carbohydrates in the $\mathrm{CPO}$ and POME waste. Optimum conditions $\alpha$-amylase obtained at $70^{\circ} \mathrm{C}$ and $\mathrm{pH} 6.0, \beta$ amylase at $60{ }^{\circ} \mathrm{C}$ and $\mathrm{pH}$ 4.0, cellulase at $40{ }^{\circ} \mathrm{C}$ and $\mathrm{pH}$ 7.0. While the use of a mixture of cellulose : $\alpha$-amylase : $\beta$-amylase with a ratio of $1: 1: 2$ at pH 5.5 and temperature $60{ }^{\circ} \mathrm{C}$ that yielded optimal $\beta$-carotene. Extractions with enzymatic methods of waste palm oil were able to isolate $\beta$-carotene of $0.19 \%$ equivalent to $1160 \mathrm{ppm}$.
\end{abstract}

Keyword: $\beta$-caroten, CPO and POME, column chromatography, and enzymatic extraction.

\section{Introduction}

Indonesia is the world's largest palm oil producer, contributing around 27.0 MTon (48.79\%) of the world in 2012 [1]. Until now most of the components of the non-oil has not been used optimally. In fact, waste palm oil industry still has a high economic value. Many palm oil processing byproducts that can be used as the basis of the oleochemical industry, one of which is $\beta$-carotene that are needed in the food, pharmaceutical, and cosmetics industries [2].

Industrial wastes such as waste liquid, solid, and gas, have great potential given becouse nearly $77 \%$ of waste oil is not used. Wastewater of palm oil in Indonesia reached 28.7 MTonnes per year [3]. While the carotenoid content of the fiber waste of 4000-6000 ppm [4]. In the edible oil industry to limit the content of $\beta$ carotene in accordance with the quality standards of the industry, many $\beta$-carotenes should be discarded [2].

Carotenoids world needs increase every year, especially for food, animal feed and pharmaceuticals (Hanafi.2004). Reports of Business Communication Company (BCC) shows that the current market value of commercially used carotenoids is nearly $\$ 1.2$ billion in 2010 , with a chance to grow to $\$ 1.4$ billion in 2018 with a compound annual growth rate of $2.3 \%$. The market value of $\beta$-carotene, around \$ 250 million in 2007, increased to just $\$ 261$ million in 2010 . This market is expected to grow to $\$ 334$ million by 2018 at a compound annual growth rate of $3.1 \%$, [5].

A total of 11 types of carotenoids in palm oil have been identified [6]. Palm oil carotenoid content varies according to the level of maturity and genotype of the fruit is about $200-800 \mathrm{ppm}$, even reaching over $1000 \mathrm{ppm}$. Composition of provitamin A carotenoids in the palm oil are $\alpha$-carotene (30-35\%), $\beta$-carotene (60$65 \%)$ and $\gamma$-carotene (5-10\%) [7].

Several methods of extracting carotenoids from palm oil among other saponification treatment, adsorption, solvent extraction, and transesterification of palm oil, followed by distillation $[6,8]$. While Kemmerer [9] isolate carotenoids, with a variety of treatments extraction process. The treatment gave the highest carotene are: the sample is dissolved in petroleum ether at room temperature with $82.2 \%$ of $\beta$-carotene and $16.6 \% \alpha$-carotene, as well as sample saponification in alcoholic $\mathrm{KOH}$ for 5 minutes at room temperature with $83.30 \% \beta$-carotene and $16.20 \% \alpha$-carotene.

Koba conduct additional bases in enzymatic reactions to facilitate the breakdown of carbohydrates in the palm oil [8]. Extraction with the help of enzymes aims to separate carotenoids from palm oil and solids.

In this study, carotenoids of Crude Palm Oil (CPO) and Palm Oil Mill Effluent waste (POME) separated by column chromatography and extraction methods with the help of enzymes. Enzymatic reaction is useful to break down the fiber and carbohydrates other types of oil and solids in oil. Results of the termination of the bond, is expected to facilitate the release of carotenoids. Extraction was conducted with the help of a 
Optimization Carotenoids Isolation Of The Waste Crude Palm Oil Using $\alpha$-Amylase, $\beta$-Amylase single enzyme of $\alpha$-amylase, $\beta$-amylase, cellulase or its enzyme mixture to break the fiber and starch polysaccharides. In addition, the saponification reaction performed on CPO to separate saponification fraction by the addition of enzyme pretreatment. The addition of complement activator serves to enzyme structure tooptimized its activities. The addition of enzyme and $\mathrm{Mn}^{2+}$ can improve increasing the yield of carotenoids extracted [10].

\subsection{Materials}

\section{Materials And Methods}

Materials used include: $\beta$-carotene pa (Merck), silica gel $43 \mu \mathrm{m}$ (Merck), CMC (Merck) and DNS (dinitrosalicyle acid) from SIGMA. Ethanol $95 \%$, petroleum ether, and n-hexane (Brata Chem). $\alpha$-Amylase enzyme, $\beta$-amylase and cellulase obtained from the distributor rough enzymes for Bioethanol Company. CPO and solid waste samples POME obtained from PTPN VIII Bandung, Indonesia.

\subsection{Determination of optimum conditions for enzymatic reactions}

\subsubsection{Determination of amylase and cellulase activity solution}

Amylase activity was determined by hydrolysis activity of amylose, while cellulase activity was tested with samples of $\mathrm{CMC}$ at $\mathrm{pH} 3-8$ using acetate or ammonium buffer. The solution was incubated at $10-90{ }^{\circ} \mathrm{C}$ temperature variation. The reaction was stopped by adding DNS reagent, and heated for 30 minutes. Cold solution was measured with a spectrophotometer Vis absorbance at $\lambda=540 \mathrm{~nm}$.

\subsubsection{Calculation of Enzyme Activity and specific activity.}

One unit of enzyme activity is expressed as the amount of enzyme that produces $1 \mu \mathrm{mol}$ of reaction substrate (glucose) in $1 \mathrm{~min}$, (U/ mL). Specific Enzyme Activity (U/mg) was obtained by determining the enzyme protein content using the method of Lowry [11].

\subsubsection{Determination of optimum reaction conditions}

Determination of $\mathrm{pH}$ optimum performed at $30{ }^{\circ} \mathrm{C}$ with varying $\mathrm{pH} 3-8$. Determination of optimum temperature variation is done by $20-90{ }^{\circ} \mathrm{C}$ at the optimum $\mathrm{pH}$ of each enzyme.

\subsection{Determination of Levels of Carotenoids from Palm Oil Samples}

\subsubsection{Sample Preparation CPO and Waste POME}

POME waste prior to use first screening performed to separate the fiber with oil. Furthermore, the fiber in the form of solids loaded and ready for use.

\subsubsection{Separation of carotenoids by column chromatography}

a. Crude Palm Oil Extraction.

Palm oil is extracted with n-hexane using a funnel with a ratio of $1: 0.6$. The extraction is distilled to produce distillate of palm oil. To obtain oil from POME used the same procedure as CPO.

b. Extraction using column chromatography.

Silica gel in the column was saturated by n-hexane. Mobile phase (eluent) used were n-hexane, ethanol 95\%, petroleum ether, or combinations thereof. Eluate fractions were collected respectively by $25 \mathrm{~mL}$. Carotenoids contained from each fraction was measured by Visible Spectrophotometer at $\lambda=443 \mathrm{~nm}$

Comparison of weight of extracted oil : silica gel varied as follows: $1: 4,1: 5$, and $1: 6$, was $2.50 \mathrm{~g}$ : $10 \mathrm{~g}, 2.00 \mathrm{~g}: 10 \mathrm{~g}$, and $1.67 \mathrm{~g}: 10 \mathrm{~g}$.

\subsection{Separation Methods of Carotenoids by Enzymatic Reactions}

\subsubsection{Separation of Carotenoids by a single enzyme}

The method used is the modified method of Cinar. Up to 20 grams of sample added to $40 \mathrm{~mL}$ acetate buffer solution with $\mathrm{pH}$ variation (adjusted to $\mathrm{pH}$ optimum enzyme). Samples were inserted into the Erlenmeyer and add as much as $1 \mathrm{~mL}$ enzyme. Each sample was added $0.90 \mathrm{~mL}$ of $150 \mathrm{mM} \mathrm{MnSO} 4$ solution $(1: 30 \mathrm{v} / \mathrm{v})$. Then, samples were incubated with a shaker for 90 minutes. Furthermore, samples were filtered using a Buchner funnel with Whatman paper no. 1. Fluid containing water filtering results is discarded. Oil residue washed with $95 \%$ ethanol solution of $50 \mathrm{~mL}$. Residues in the form of carotenoids extracted further with $2 \times 10 \mathrm{~mL} \mathrm{n}$-hexane. Determined the levels of carotenoids extracted as $\beta$-carotene.

\subsubsection{Separation of Carotenoids by a single enzyme and saponification treatment}

The same treatment was used as in the use of a single enzyme. The difference when mixed shaker, add by $5.0 \mathrm{~mL}$ of $3.0 \mathrm{M}$ alcoholic $\mathrm{KOH}$ solution for saponification reaction during 30 minutes. Subsequently, the solution was neutralized prior to the screening.

2.4.3. Separation of Carotenoids with a combination of Enzymes 
The same treatment as the addition of a single enzyme, the difference is an enzyme that is used is a combination of $\alpha$-amylase : $\beta$-amylase : cellulose, respectively $(1: 1: 1),(1: 1: 2),(1: 2: 1),(2: 1: 1)$ and the variation in temperature of $40{ }^{\circ} \mathrm{C}, 50^{\circ} \mathrm{C}, 60^{\circ} \mathrm{C}$.

\section{RESULTS and DISCUSSION}

\subsection{Determination of optimal conditions for enzymatic reactions}

\subsubsection{Determination of enzyme activity}

The results showed that the enzyme activity unit used is: $\alpha$-amylase $(1.882$ units $/ \mathrm{mL}), \beta$-amylase (3.271 units $/ \mathrm{mL})$, and cellulase $(0.136$ units $/ \mathrm{mL})$, with a specific activity of 0.139 units $/ \mathrm{mg}$ ( $\alpha$-amylase), 0.049 units/mg ( $\beta$-amylase), and 0.426 units $/ \mathrm{mg}$ (cellulase).

\subsubsection{Determination of Optimum Conditions Enzymes}

$\mathrm{pH}$ optimum results shown in Figure 1, the $\mathrm{pH}$ optimum cellulase obtained is 7.0, $\alpha$-amylase at 6.0, and the $\beta$-amylase at $\mathrm{pH} 4.0$. While the optimum temperature, $\alpha$-amylase at $70{ }^{\circ} \mathrm{C}, \beta$-amylase at $60{ }^{\circ} \mathrm{C}$, and at 40 ${ }^{\circ} \mathrm{C}$ cellulases.
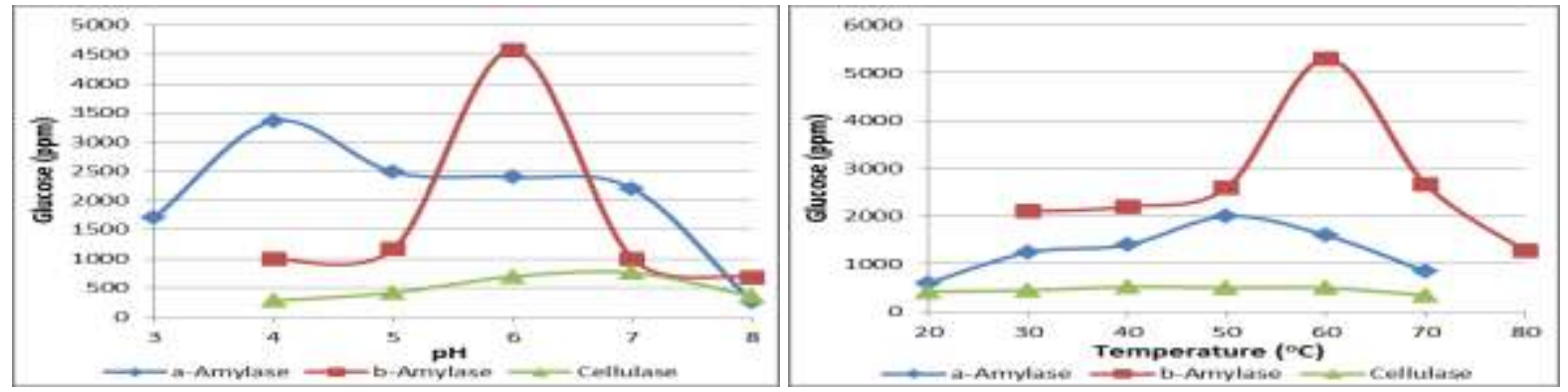
Figure 1. Optimum enzymatic condition (pH and temperature) for $\alpha$-Amilase, $\beta$-Amilase, and
Cellulase.

Based on theresults of the optimizationis done then the optimal conditions of enzymes used are summarized in Table 1. Compared with other researchs, shows that the optimum conditions obtained almost the same.

Table 1.The results of $\mathrm{pH}$ and temperature optimization of enzymatic reactions and the extraction of $\beta$-carotene.

\begin{tabular}{|l|c|c|c|c|c|c|}
\hline \multirow{2}{*}{ Enzym } & \multicolumn{2}{|c|}{ The results } & \multicolumn{2}{c|}{$\begin{array}{c}\text { The research results of } \\
\text { other researchers }\end{array}$} & \multicolumn{2}{c|}{ Extraction of $\beta$-carotene } \\
\cline { 2 - 7 } & $\mathrm{pH}$ & $\mathrm{T}\left({ }^{\circ} \mathrm{C}\right)$ & $\mathrm{pH}$ & $\mathrm{T}\left({ }^{\circ} \mathrm{C}\right)$ & $\mathrm{pH}$ & $\mathrm{T}\left({ }^{\circ} \mathrm{C}\right)$ \\
\hline$\alpha$-Amylase & 6.0 & 70 & $5,5-5,6^{\mathrm{a}}$ & $80-90^{\mathrm{a}}$ & 7 & 50 \\
\hline$\beta$-Amylase & 4.0 & 60 & $4,1-4,3^{\mathrm{a}}$ & $60-62^{\mathrm{a}}$ & 5 & 30 \\
\hline Cellulase & 7.0 & 40 & $6,85^{\mathrm{b}}$ & $40^{\mathrm{b}}$ & 6 & 30 \\
\hline
\end{tabular}

Notes: a. Hamdani research, and b. Styani research.

\subsection{Sample Extraction of Carotenoids from CPO.}

Carotenoid levels of CPO conducted as a preliminary test before the waste solids of palm oil. In addition, preliminary tests are also conducted to compare the column chromatography method with the method of enzymatic reactions, a known method that can produce the highest levels of carotenoids. Carotenoid concentrations expressed as $\beta$-carotene concentration.

3.1.1. Extraction of carotenoids by column chromatography

a. Carotenoids extracted with a single eluent.

The solvent extraction carotenoid results are shown in Figure 2a. It appears that the solvent $n$-hexane to extract the oil component of more than $95 \%$ ethanol and petroleum ether. This suggests that the more carotenoid isolated from the oil component. The disadvantage was many other components extracted by the solvent, it means that $n$-hexane be less selective. To overcome this, the next treatment is the separation by column chromatography with a suitable eluent. 
Optimization Carotenoids Isolation Of The Waste Crude Palm Oil Using $\alpha$-Amylase, $\beta$-Amylase

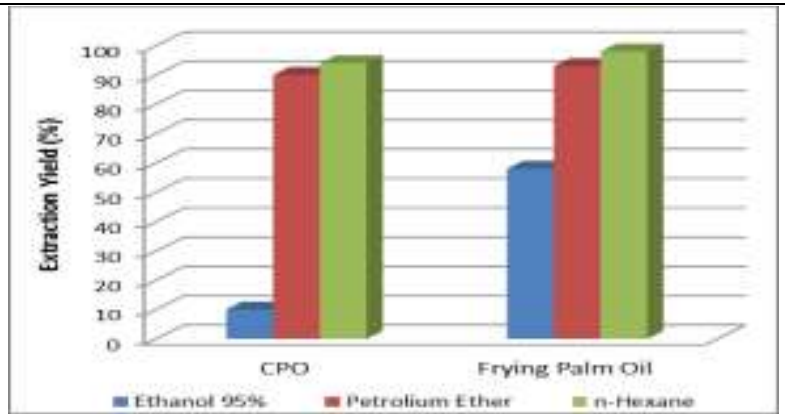

(a)

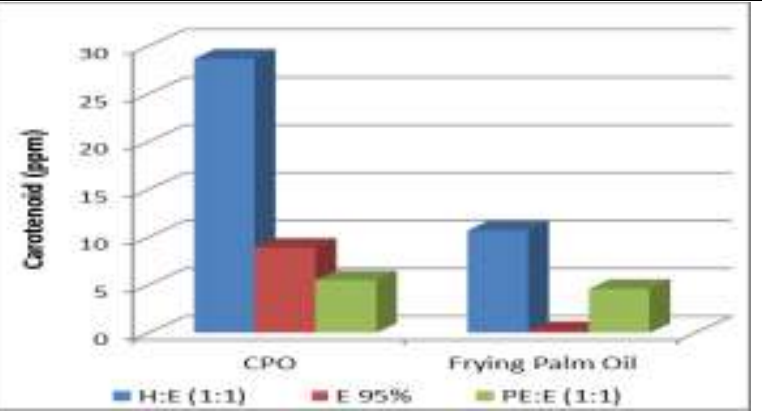

(b)

Figure 2. Carotenoid extraction yield using (a) singgle organic eluen, (b) mix of 2 organic eluent (v:v) H (n-hexane), E (ethanol 95\%), PE (petrolium ether)

b. Extraction with the eluent mixture.

The determination of the exact composition of the eluent for the separation of carotenoids performed using eluent mixture. Eluent mixture tested include: n-hexane : ethanol $95 \%(1: 1)$, ethanol $95 \%$, and ethanol $95 \% 95 \%$ : petroleum ether $(1: 1)$. The results can be seen in Figure $2 b$. The composition of n-hexane : ethanol $95 \%(1: 1)$ separated the carotenoids with higher concentrations of eluents compared others.

Further determination of the composition of the sample : silikagel that can produce the highest concentration of carotenoids extracted. In practice, made the comparison sample : silikagel with variation $(1: 4)$, $(1: 5)$, and $(1: 6)$. Elution with n-hexane : ethanol $95 \%(1: 1)$. The results can be seen in Figure 3.

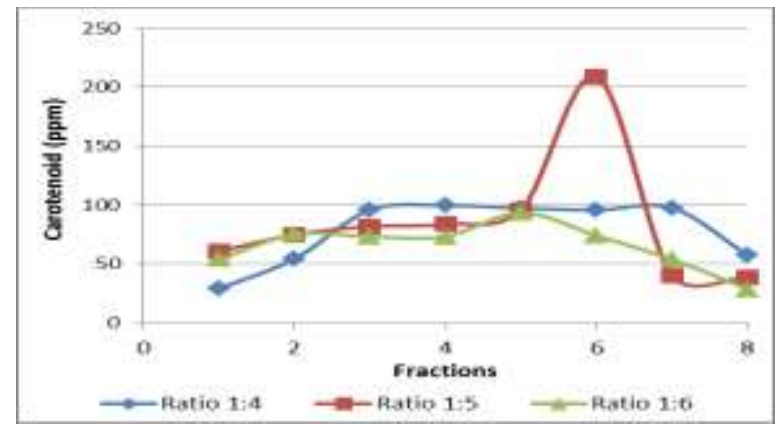

Figure 3. Ratio of gel silica : sample (w:w). (a) 1:4, (b) $1: 5$, and (c) $1: 6$

Based on Figure 3, note that the highest concentration of carotenoids produced by the comparison sample: silikagel $(1: 5)$ in the fraction-6. This suggests that the small sample size ratio, more carotenoid compounds retained by silikagel. While the ratio of the number of samples is higher, silikagel too saturated by the sample thus inhibiting carotenoid distribution by eluent. This causes the small amount of carotenoids that can be separated.

\subsubsection{Carotenoid extraction with the help of Enzymatic Reactions}

a. Carotenoid extraction with the help of a single enzyme.

The results of the analysis of carotenoid extract from enzymatic reactions with the help of a single enzyme: $\alpha$-amylase, $\beta$-amylase, or cellulose against palm oil can be seen in Figure 4.

Based on Figure 4, the highest carotenoid levels obtained with the help of $\alpha$-amylase enzyme at $\mathrm{pH} 7.0$, temperature $50{ }^{\circ} \mathrm{C}$ and $\beta$-amylase at $\mathrm{pH} 5.0$, temperature $30{ }^{\circ} \mathrm{C}$ and cellulase at $\mathrm{pH} 6.0$ and temperature $30{ }^{\circ} \mathrm{C}$. In comparison, there was a slight shift in $\mathrm{pH}$ and temperature of the enzyme optimum $\mathrm{pH}$ and temperature to produce the highest concentration of carotenoids. Summary of optimization $\beta$-carotene extraction is shown in Table 1. The shift in $\mathrm{pH}$ and temperature optimum extraction of carotenoids can be seen in Figure 5.

Based on Figure 5, seen that the change of $\mathrm{pH}$ optimum gave the highest carotenoid. This is due to the fiber content of the matrix and other carbohydrates that can be broken down by the enzyme cellulase, $\alpha$ amylase, and $\beta$-amylase.

In the graph of temperature (Figure 5b), so the temperature of the extraction to get the highest carotenoids are always lower than the optimum temperature of the enzyme. It is related to the stability of carotenoid. The difference in optimum temperature and optimum extraction of cellulase is not too big, for cellulase optimum temperature $\left(40{ }^{\circ} \mathrm{C}\right)$ is not too far from carotenoids stable temperature around room temperature. While the $\alpha$-amylase and $\beta$-amylase, the enzyme optimum temperature of both the $60{ }^{\circ} \mathrm{C}$ and 70 
${ }^{\circ} \mathrm{C}$, higher with temperature stabilized carotenoids. So the double bond in the carotenoid compound is not stable at this temperature and may be damaged.
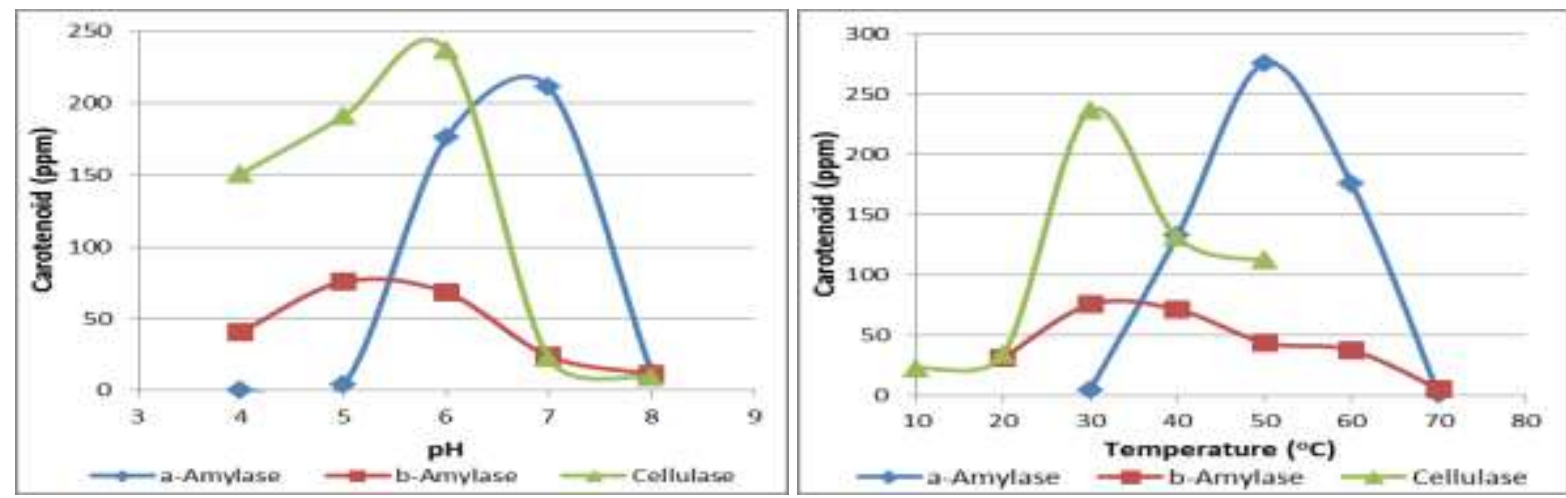

Figure 4. Optimum conditions ( $\mathrm{pH}$ and temperature) carotenoids extraction in $\mathrm{CPO}$ using $\alpha$-amylase (pH 7.0, 50 $\left.{ }^{\circ} \mathrm{C}\right) ; \beta$-amylase ( $\left.\mathrm{pH} 5.0,30{ }^{\circ} \mathrm{C}\right)$, and Cellulase $\left(\mathrm{pH} 6.0,30^{\circ} \mathrm{C}\right)$.

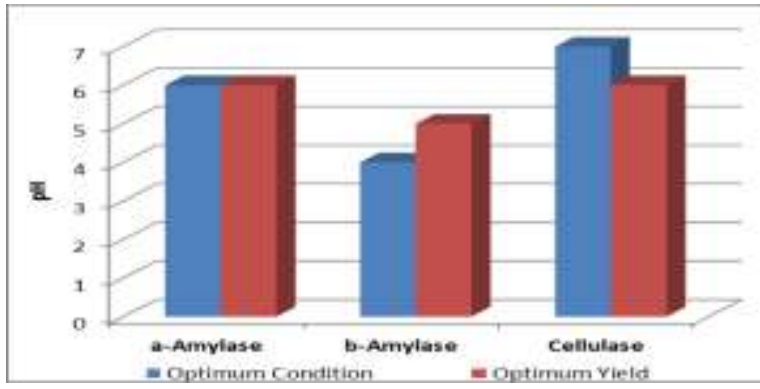

(a)

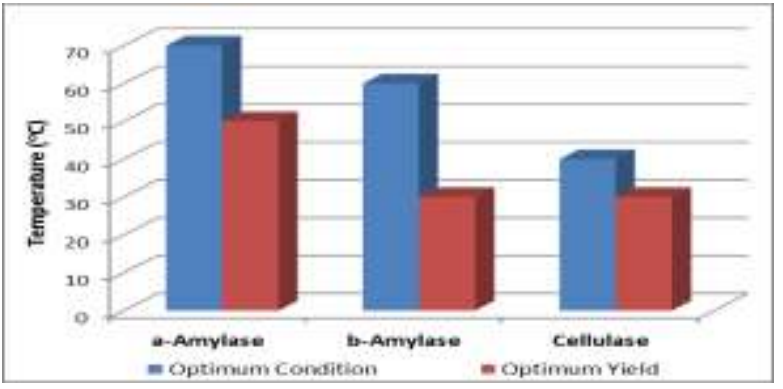

(b)

Figure 5. Shiftting of enzymes optimum conditions (pH and temperature) on the optimum extraction conditions of High Carotenoid results.

The addition of incubation time also increases the activity of extraction to achieve optimum conditions. Highest carotenoid extracted with the aid of cellulase obtained at the time of 150 minutes, $\alpha$-amylase at 90 minutes, and the $\beta$-amylase obtained at 60 minutes. Cellulase enzymes had optimum time is longer, followed by $\alpha$-amylase, and $\beta$-amylase, it is related to the activity of the enzymes used. Cellulase enzyme activity of the small causes the enzyme requires a longer time to break down the cellulose substrate is in the form of palm oil fiber rude. $\beta$-amylase enzyme has the greatest activity so it takes less time to break down carbohydrates other than cellulose so that the carotenoids are attached to the carbohydrate matrix can be removed more quickly.

b. Determination of Carotenoids with a combination of Enzymes.

$\alpha$-amylase, $\beta$-amylase, and cellulase used have the same goal of breaking the fiber matrix of carotenoids and other carbohydrates. Extraction with a combination of enzymes performed at $\mathrm{pH} 5.5$ is a $\mathrm{pH}$ optimum of the three enzymes. The work variations and combinations of these three enzymes incubation temperature variations can be seen in Figure 6.

Based on the diagram combination of enzymes with variations in temperature, concentration of carotenoids tended to increase with increase in temperature (Figure 6a). The highest carotenoid concentrations obtained with the combination of $\alpha$-amylase : $\beta$-amylase : cellulose with a ratio of $1: 1: 2$. It can be associated with a temperature optimum enzyme $\beta$-amylase and $\alpha$-amylase at $60{ }^{\circ} \mathrm{C}$. Extraction of carotenoids used the greater composition cellulose showed the increasing of concentrations. It is also associated with an optimum temperature of each enzyme that generated carotenoid concentrations tend to follow the trend of increases and decreases in temperature during the reaction.

\subsection{Determination of Levels of Carotenoids from POME Waste}

The addition of enzyme to the CPO sample obtained $\beta$-carotene higher than extraction using column chromatography. Thus, for the determination of levels of $\beta$-carotene from POME wastewater was conducted by the enzymatic reaction. The enzyme is selected was sellulase enzymes that was espected can release the carotenoid with the highest concentration compared to $\alpha$-amylase and the $\beta$-amylase. 

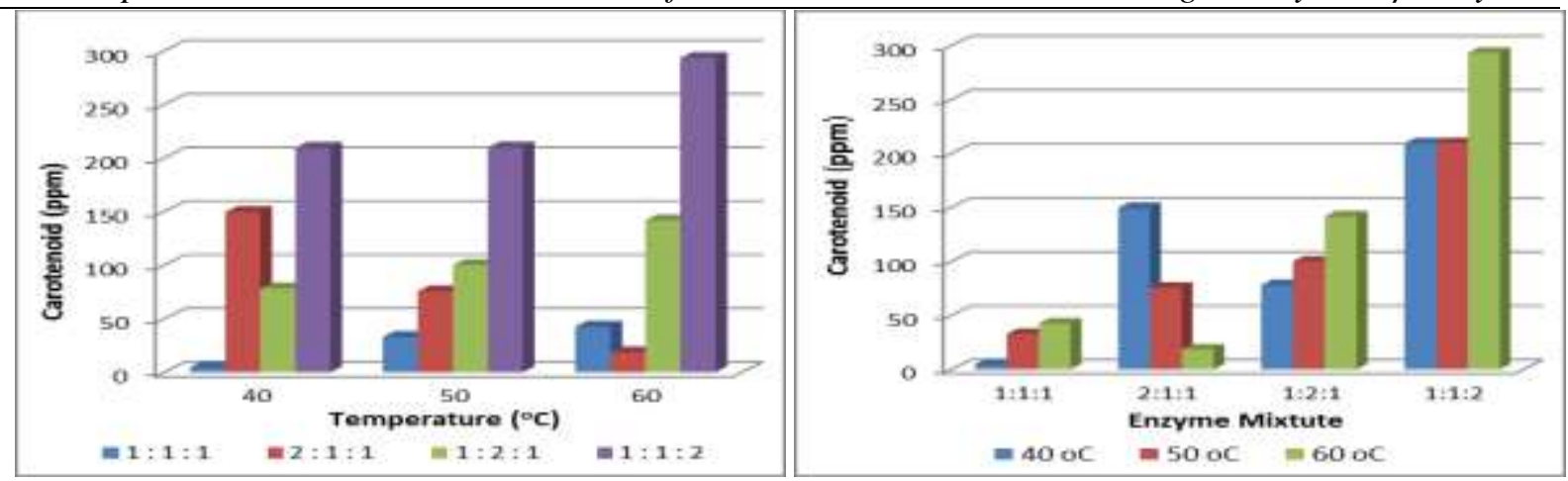

Figure 6. Mixture of various comparison $\alpha$-amylase, $\beta$-amylase, and cellulase on the extraction of carotenoids

Modification method of carotenoids separation by enzymatic reactions carried out by the addition of alcoholic $\mathrm{KOH}$ solution after the enzymatic reaction is complete, then refluxed for 30 minutes in order to separate the fats/oils and fatty acids contained in the fraction of palm oil with unsaponifiable fractions. From this process, the concentration of carotenoids obtained is $953 \mathrm{ppm}$. The concentration is decreased when compared to the concentration of carotenoids treated without reflux is equal to $1160 \mathrm{ppm}$. This is because during the boiling, partially of carotenoid molecules was broken. This phenomenon is in accordance with the results of Kemmerer [9] which showed that the addition of alcoholic $\mathrm{KOH}$ solution without boiling produced higher $\beta$ carotene levels.

\section{Conclusion}

Palm oil waste contains $\beta$-carotene of $0.19 \%$, which can be isolated using the enzymatic reaction. Separation of carotenoids by enzymatic reaction method is better than the separation of carotenoids by column chromatography method. $\alpha$-Amylase, $\beta$-amylase, and cellulase may help release carotenoids from the matrix of fibers and other carbohydrates in the CPO and POME waste.

\section{Refferences}

[1]. Noname. (2011). Palm Oil Production by Country in 1000 MT. http://www.indexmundi.com/agriculture/ ?commodity=palm-oil\&graph=production.

[2]. Ahmad, A.L., Chan, C.Y. and Sunarti, A.R. (2009). Isolation of Carotenes from Palm Oil Mill Effluent and Its Use as A Source of Carotenes. School of Chemical Engineering, Engineering Campus, Universiti Sains Malaysia, Pinang, Malaysia

[3]. Ministry of Industry Indonesia. (2007). Palm Oil Industry Overview. Jakarta: Secretariat General of the Ministry of Industry.

[4]. May, Choo Yuen. (1994). Palm Oil Carotenoid. Food and Nutrition Bulletin, $\quad$ volume 15, number 2 , june

[5]. Noname. (2012). The Global Market of Carotenoid. (http://www.bccresearch.com/report/carotenoids-global-marketfod025d.html).

[6]. Ping, Bonnie Tay Yen. (2006). Palm Carotenoids Profile as A Quailty Control Tool for Palm Carotene Producers ; Introducing An Improvised Method by HPLC-Photodiode Array and A C30 Column. 18th of December

[7]. Wei, P.C. and May, C.Y. (2005). Supercritical Fluid Extraction of Palm Carotenoids. Kuala Lumpur : Department of Chemistry, Faculty of Science, University of Malaya

[8]. Koba, Yojiro and Ayaazaki Ishizaki. (1989). Chemical Composition of Palm fiber and Its Feasibility as Cellulosic Raw Material for Sugar Production.Fukuoka. Department of Food Science and Technology, Faculty of Agriculture, Kyushu University

[9]. Kemmerer, A.R. and Fraps, G.S..(2007). Constituent of Carotene Extracts of Plants.Texas. Texas Agricultural Experiment Station

[10]. Styani, Erna. (2006). Total Carotenoids Extraction of Fruit Papaya (Carica papaya L.) Using pectinase-cellulase enzyme. Theses, Chemistry Graduate Study, Faculty Mathematics and Science, University of Indonesia. Depok, Indonesia.

[11]. Waterborg J.H., 2002. The Lowry Method for Protein Quantitation. Springerlink 